\title{
1. Introduction to the Research Handbook on the Law and Politics of Migration: law, politics, and the spaces between
}

\author{
Catherine Dauvergne
}

The law and politics of migration are increasingly intertwined. Over the past two decades, migration has moved to the centre of the political agenda in all Western liberal democracies, in many states of the global South, as well as in those states that migration scholars often label transit states, which are sites of both arrival and departure and which are neither the West nor the global South. This move to the political centre has been accompanied by growing attention to the legal frameworks for migration, and a tremendous expansion of regulation in an area that was marked as recently as the 1980s and 1990s by high levels of discretionary decision making and a comparative scarcity of legal pronouncements. Not surprisingly, the vectors of politicization and legalization are intertwined and interdependent. This Research Handbook focuses on this overlapping terrain.

Key contemporary political shifts have been strongly influenced by migration matters. One need only think of the role played by immigration politics in the Brexit debates, the number of immigration initiatives championed by the Trump government, or the massive forced migration that followed the Arab Spring to have a sense of the political importance of migration at present. All of this was apparent prior to the emergence of the COVID-19 pandemic early in 2020, which served to remind the world that it is still possible for powerful states to close their borders in the face of threats. Indeed, the pandemic threat has proven so significant that opposition to border closings has been scant indeed. The pandemic has rendered closed borders natural and logical in a way that might set migrant advocacy back by decades or more.

In the face of this shift towards a complete intermingling of migration law and migration politics, our old frameworks for understanding each of these phenomena are increasingly inadequate. This Research Handbook probes the weaknesses of our older frameworks and aims to chart new directions.

The undercurrent of the contributions in this Handbook is that the law and politics of migration cannot be separated from one another at this point in the trajectory of research about migration. One can pull at this thread from either end. From the point of view of legal scholars, the rate of change of migration laws has grown exponentially in the twenty-first century. Where much of the architecture of migration regulation could formerly be attributed to nation-building aspirations, a fuzzy but persistent economic logic, and a scarcely relevant international sphere, the nuts and bolts of migration law provisions have become an area in which the frequently studied prosperous Western states are making new rules at regular intervals, and states in the global South, which have scarcely been noticed by Western scholars, are beginning to develop approaches to migration regulation that command attention. In the once paradigmatic 'nations of immigration' (the United States, Canada, Australia, and to some extent New Zealand), some aspects of the legal frameworks for immigration have been altered 


\section{Research handbook on the law and politics of migration}

so dramatically in the past decade that the core principles of a nation built from migration have disappeared. ${ }^{1}$ Alongside this shift in these much studied stalwarts of migration scholarship come other important alterations that challenge the orthodoxy of migration research. The long-held line between temporary and permanent migration has come to stand for little more than a fervent nostalgia of states. The important distinction between refugees, who have strong rights in the international realm, and migrants, who have almost none, has faded even further. This is an ironic development, to be sure, because the past decade has seen more refugees than any previous time in history, and because international refugee law is proving increasingly strong, despite being under attack almost everywhere on earth. The irony arrives because in the face of these two developments, analysts increasingly write of migrants as an umbrella term, and those of us old enough to be 'old-fashioned' refugee law scholars increasingly write of security effects that invariably affect refugees and other migrants similarly. In this way, the politics of refugee law is itself pushing the law aside.

Beginning by tugging at the politics end of the thread is equally productive and complex. The early twenty-first century days when minister of migration was a minor cabinet post in most Western liberal democracies are long gone. The political importance of migration is vital in the majority of states around the globe. The COVID-19 pandemic laid bare this phenomenon as it filled our television screens with images of Indian migrant workers dispatched home in haste, of Chinese nationals stranded in Beijing or Shanghai away from their registered homes, of states from around the globe chartering planes to bring diasporic members back within their closed borders, and of how those same closed borders put both food production and migrant remittances in peril around the globe. In addition to the manifest salience of migration to both electoral and everyday politics, the contemporary era is marked by a legalization of this politics. This legalization has arisen in part because the contested terrain of migration politics is often the courts - a perhaps inevitable outcome of rapid growth in the volume of regulation and of deep disputes drawing on the rhetoric and procedural power of human rights. It results as well from increasing use of the strongest tools of state power to insist on exclusion, a move that shifts these politics to the centre of disputes about where the true limits of state power lie. This exploration of limits brings matters of migration to the very centre of questions about what constitutes politics and political legitimacy. In this sense, migration is no longer a question of preconditions for political community, no longer a question solely at the margins.

This book takes up the law and politics tension across several sites, and from a range of disciplinary perspectives. The opening section comprises chapters that interrogate this tension broadly. Bloemraad postulates several intertwined explanations for the law and politics overlap, and suggests fruitful directions to move research forward along this fault line. Ellermann and O'Hearn's work builds on this beginning by calling our attention to what is neglected when a focus on migration law and politics overlooks Indigenous presence. This is one of the most pressing, and most difficult, issues for migration scholars in the traditional 'nations of immigration', where immigration narratives have been an important colonial tool for making Indigenous peoples invisible. The chapters by Chung and Kaushal each contribute to broadening the frame by addressing important questions of citizenship. Chung looks at the migration and citizenship politics of East Asian states and offers a challenge to Western framings of both migration and belonging. Kaushal considers how aspects of membership and community are constitutionalized, and the ways in which contemporary politics are making membership more fragile. Like Chung, she prods at the notion that citizenship is capable of accounting fully for membership in a political community. Marsden, Tucker, and Vosko's 
chapter rounds out the opening section by demonstrating the persistent slippage in discourses about migrant labour, a slippage which papers over a deep societal uncertainty about how to understand, and therefore to regulate, migrant labour. Together, this group of chapters provides explanations for how and why the law and politics of migration intertwine.

The second section of the book examines institutions of migration management and the pressures that are changing them. This collection of analyses, offered by authors from five disciplines, deepens our insight into the merging of law and politics by querying the internal functions of institutional landmarks in the sphere of migration governance. One contribution here is, of course, to establish what those landmarks are. In the opening chapter of this section, Paquet and Côté-Boucher consider the role of bureaucratic institutional cultures in migration enforcement and unearth subtle and not-so-subtle shifts that have taken place within these cultures in recent years. Madokoro looks at the notion of sanctuary, revealing how it has been a sustaining institution of migration management for centuries, and how it has been politicized distinctly at different moments in time. Labman and Zell recount how categories which scholars and states have used to categorize migrants for at least half a century have been shifted from within by current political forces. Vives and Williams demonstrate how statistics offered by state and non-governmental organizations generate an image of who counts, and who does not, in our global understanding of migration. This analysis shows quite powerfully that data is a vital aspect of our institutional architecture for governing migration. The final two chapters in this section point us towards new institutional aspects of migration, compelling us to reflect on current pressures on migration governance that, from an advocate's point of view, come from opposing directions. Hamlin's work calls our attention to the increasing influence of big technology corporations in migration management and chillingly demonstrates how their power has moved well beyond that of states. Bond's contribution presents an analysis of an effort at international scale to establish private sponsorship of refugees as a truly global institution.

Courts are themselves a central institution of contemporary migration governance; so much so that an entire section is devoted to them. The contributions here evince that the story of courts and migration has changed a great deal in the opening decades of the twenty-first century. The collective narrative of these analyses is vastly different from what one would have read 20 years ago. This is no longer a time for a hagiography of human rights, and the accompanying veneration of liberal values. What is most apparent here is that Western scholars have by and large ignored the courts of the global South, that those courts are equally engaged on questions of migration and membership, and that we must globalize our view of courts if we are to understand their role in the politics of migration. Spijkerboer opens this section with attention to how the orthodoxy of international law ignores the generative work of courts (and scholars) in the global South, and demonstrates what is lost in this manoeuvre. Juss calls our attention to the failure of courts in the United Kingdom to rise to the challenge of inclusion for Muslim refugees. Galloway's contribution presents an indictment of Canadian courts for their failure to produce rights jurisprudence capable of addressing twenty-first century realities. Foster and Roberts complete this section of the book with a provocative chapter comparing the work of courts in India and the Dominican Republic when confronted with questions of mass denationalizations. These cases provide a powerful backdrop against which to consider the politicization of courts and to query their capacity or willingness to enshrine the rule of law at community boundaries. Together these chapters introduce new directions for analysis of the political work of courts, and the politics of our choices about to which courts we attune. 
The fourth group of chapters takes a considered look at an area of intense recent expansion in migration management: the sharp end of state power. Looking at the ways in which states act to search, detain, reject, exclude, and repulse non-members, this quintet of chapters exposes the ugliest features of migration governance. Bosworth opens this section with reflections drawn from more than a decade of detailed empirical work on migrant detention in the United Kingdom. Her conclusions highlight the incredible complexity of racism in this context, and call upon us to understand how this complexity reverberates throughout our understanding of migration. Ghezelbash calls our attention to hyper-legalism as a state tactic, a political device allowing states to strip law of its most robust intent. Like Ghezelbash, Vogl draws her empirical examples from Australia, the global hegemon of punitive migration powers. Vogl's analysis deftly shows how the entanglement of criminal and migration laws now known as 'crimmigration' takes on extravagant dimensions when one focuses on those seeking asylum in particular. This work provides a sharp insight into the deleterious human rights consequences of failing to politically disentangle migrants and refugees. Arbel and Joeck's chapter offers a completely original analysis of migrant detention by looking at how the COVID-19 pandemic has very quickly ushered in changes in detention patterns in Canada, arguing that these changes portend a system overhaul. Goold's insights into how privacy rights are degraded in border settings by conceptualizing the border as exceptional completes the section's review of the often unchecked reach of the state in migration settings.

The concluding group of chapters addresses international governance of migration and provocatively suggests that the relationship between law and politics is at once the only thing that makes governance possible, and the very thing that seems to guarantee that success is perpetually just over the horizon. Abu-Laban's work opens this section with a clear-headed reflection on the contrast between the governance regimes for Palestinian refugees on the one hand, and all other refugees on the other. Her argument that much could be gained by dissolving the distinction between the two regimes shows how the political tensions of the mid-twentieth century are preserved in the present day. Abu-Laban's chapter is a perfect example of how high-stakes politics impairs the development of functional law.

The four chapters that follow address the most recent international governance innovation, the Global Compact for Safe, Orderly and Regular Migration approved by the United Nations General Assembly in December 2018. This newest of international instruments exists at the present moment as promise and potential, yet untested. It was deliberately designed as more politics than law, skirting the requirement that states take on specific obligations as part of their support of it. This Global Compact will certainly be the centre of attention for migration scholars in the near term. Watson and Robinson draw on actor-network theory to evaluate whether the Compact successfully mediates the knowledge controversies that surrounded its development, and conclude that the Compact functions in a realm of ontological politics. Grey takes as a starting point the troubling idealism of the Compact and argues that its value is as a 'social theodicy' in the Rawlsian sense: an ideal that can serve to reconcile the world to large-scale migration. Guild assesses the Compact's potential to bring us closer to the Sustainable Development Goals that ostensibly inspired it despite compelling evidence that a development logic does not, in fact, underpin much South to North migration. She asserts that despite opposition from some significant actors such as the United States, the Compact does succeed in changing the landscape of international governance through its insistence on cooperation between states, and through states' acknowledgement of cooperation as a norm. Hennebry and Piper consider the Compact from the perspective of labour rights for migrant 
workers. They argue that during the development of the Compact, private sector corporate actors occupied the same terrain as traditional civil society groups, leading to a conflation of views and a degrading of rights advocacy. The result is that while the Compact moves towards increasing international governance, it does so through a sharp rise in privatization. Each of these chapters provides a grounding for future assessments of the Compact as implementation moves forward in the near term. The Compact will be a significant test of how and whether the law and politics of migration can intertwine towards progressive outcomes at a juncture in history when migration politics are especially mean-spirited in many corners of the globe.

This concluding cluster of chapters on the Global Compact for Safe, Orderly and Regular Migration points us towards two noteworthy absences in this collection. The first is the absence of analyses of the Global Compact on Refugees, concluded at the same time as the Migrants Compact. The straightforward explanation for this is that the Compact on Refugees simply lacks enough originality to trigger scholarly attention. For the most part, the Compact on Refugees does little more than gather together existing (and frequently neglected) commitments, and reinforce state sovereignty. ${ }^{2}$ The existence of two compacts rather than one integrative instrument serves to underline that states have an interest in keeping refugees analytically distinct from other migrants (an interest which is anchored in the commonplace desire to preserve sovereignty), and that this interest is paralleled by refugee advocates (whose interest is in preserving the strong rights regime of the Refugee Convention). The separation of refugees and migrants serves both of these purposes well. But it ensures that analysis of the law and politics of migration is impaired by failing to keep all the complexities in view simultaneously. Bloemraad confronts this problem directly, and several other contributors (Vogl; Ghezelbash; Galloway; Vives and Williams) present work that engages directly with the problem and demonstrates its consequences. Despite this, more attention to what is lost by embracing the analytical separation of migrants and migrants-who-are-refugees would be an important addition in some future iteration of a handbook on the law and politics of migration.

The second notable absence that is highlighted by the concluding group of chapters is the lack of work that begins from a global South perspective. Spijkerboer addresses this persistent problem in Western migration scholarship head-on in his chapter, and offers a cogent account of the explanations for this pattern. But aside from including such an account, this Handbook does not succeed in countering this trend. This too ought to be a next-step priority for future scholars. The story of the work collected here sheds some light on why this pattern persists: aside from the specific national case studies, each of these chapters attunes to the global South; the chapters focused on international governance engage the global South directly; much of this work is highly original, and takes inspiration from a deep concern about people and lives in global South states. None of this is the same as beginning this enterprise from a Southern perspective and with a Southern voice.

At the time of writing, the globe is six months into the COVID-19 pandemic. It is already apparent that the pandemic is challenging global and local understandings of migration. Remarkably, several of the chapters in this book are already offering interpretations of the import of COVID-19 - a risky but tantalizing enterprise in mid-2020, to be sure. It is still possible to hope, as I do, that the pandemic may subside, thwarted by vaccine, over the coming year. If that comes to pass, the new normal may not look so terribly different from the old. But if this optimism proves foolhardy, COVID-19 may yet stress the linkage between the law and politics of migration to such an extent that utterly new forms emerge. 


\section{Research handbook on the law and politics of migration}

The principal achievement of this Handbook is to demonstrate the increasing overlap between migration law and migration politics. This is a fraught terrain, where the past two decades have brought significant change, marking a path that is very different from that of the twentieth century. A complete intertwining of law and politics puts the rule of law in peril. This collection provides ample evidence of such peril. Given the amplification in recent years of states' most draconian powers, there is a vital need for the rule of law. The work presented here suggests that we have yet to heed this warning. Indeed in the international sphere, the Global Compact for Safe, Orderly and Regular Migration (especially in contrast to the Compact on Refugees) suggests we are in danger of being seduced by the deceptive ease of politics in comparison with the sharp lines of law. It is in the space between law and politics that the rule of law can - must - thrive. It is this space that migrant advocates must urgently work to preserve, and that scholars must continue to chart.

\section{NOTES}

1. This is an argument that I explored at length in The New Politics of Immigration and the End of Settler Societies.

2. See James C Hathaway (2018). See also, the entire collection of articles in the International Journal of Refugee Law (2018) volume 30, issue 4.

\section{WORKS CITED}

Dauvergne, C. (2016) The New Politics of Immigration and the End of Settler Societies, New York: Cambridge University Press.

Hathaway, J. C. (2018) 'The Global Cop-Out on Refugees', International Journal of Refugee Law, 30(4): 591-604. 